\title{
ПІДГОТОВКА БАКАЛАВРІВ 3 КОМП’ЮТЕРНОЇ ІНЖЕНЕРІЇ У ГАЛУЗЕВИХ СТАНДАРТАХ ВИЩОЇ ОСВІТИ УКРАЇНИ
}

Сорокопуд М. А. Підготовка бакалаврів 3 комп’ютерної інженерії у галузевих стандартах вищої освіти України.

У статті розглянуто основні підходи до підготовки бакалаврів 3 комп’ютерної інженерії в Україні. Здійснено аналіз професійних компетенцій майбутніх фахівців. Розглянуто розподіл загального навчального часу за циклами підготовки та розподіл годин за дисциплінами циклу математичної та природничо-наукової підготовки. Визначено роль фізики в підготовці майбутніх фахівців.

Ключові слова: бакалавр, комп’ютерна інженерія, підготовка фахівців, галузевий стандарт, фізика.

Сорокопуд М. А. Подготовка бакалавров компьютерной инженерии в отраслевых стандартах высшего образования Украины.

В статье рассмотрены основные подходы к подготовке бакалавров в области компьютерной инженерии в Украине. Проведен анализ профессиональных компетенций будущих специалистов. Рассмотрены распределение общего учебного времени по циклам подготовки и распределение часов по дисциплинам цикла математической и естественнонаучной подготовки. Выделена роль физики в подготовке будущих специалистов.

Ключевые слова: бакалавр, компьютерная инженерия, подготовка специалистов, отраслевой стандарт, физика.

Sorokopud M. A. of Bachelors' of computer engineering training according to the industry standards of higher education in Ukraine.

The article considers the main approaches to the Bachelors' of computer engineering training in Ukraine. The analysis of the professional competences of the future specialists was carried out. A general study time sharing by cycles of training and hours sharing by disciplines of mathematics and natural science was considered. The role of Physics during the process of future specialists training was emphasized.

Key words: bachelors, computer engineering, Bachelors' training, industry standard, Physics.

Соціально-економічні зміни, які відбуваються у суспільстві, потребують якісно нового рівня підготовки фахівців різного профілю. Професійна підготовка фахівців 3 інформаційних технологій в Україні ведеться за кількома напрямами підготовки, провідним 3 яких є напрям 6.050102 «Комп’ютерна інженерія». Комп’ютерна інженерія - сучасний напрям підготовки фахівців в галузі інформаційних технологій, що поєднує інформатику й комп’ютерні мережні технології, а також універсальні та спеціалізовані комп’ютерні системи. Комп’ютерні інженери - це фахівці з комп’ютерних мереж і технологій, що мають інтегровану професійну підготовку в галузі комп’ютерної схемотехніки, системного програмування й інтеграції апаратно-програмного забезпечення. Завдання, пов’язані 3 комп’ютерною інженерією, передбачють написання програмного i мікропрограмного 
забезпечення для мікроконтролерів, проектування інтегральних схем, вузлів і пристроїв обчислювальної техніки, розроблення операційних систем, цифрових систем керування й контролю для завдань робототехніки. Ця галузь інженерії зосереджена не тільки на самій роботі комп’ютерних систем, але й на їх інтеграції.

Meта статmі - аналіз нормативної бази підготовки бакалаврів за напрямом 6.050102 «Комп’ютерна інженерія» в Україні, зокрема визначення ролі, місця та змісту курсу фізики у професійній підготовці фахівців.

Узагальнений об’єкт діяльності комп’ютерних інженерів - технічні (апаратні) засоби й системне програмне забезпечення комп'ютерних систем та мереж універсального і спеціального призначення та їх компонент. Після закінчення ВНЗ за напрямом підготовки 6.050102 «Комп’ютерна інженерія» випускники здобувають кваліфікацію 3121 «Фахівець 3 інформаційних технологій» [3].

Професійне призначення фахівців з комп’ютерної інженерії передбачає роботу на підприємствах та в організаціях, що здійснюють розроблення та виробництво технічного і програмного забезпечення комп’ютерних засобів, систем, комплексів та мереж; установах державного управління та підприємництва; банківських установах, митницях; енергетичних, газотранспортних та нафтотранспортних підприємствах; правоохоронних та військових установах; організаціях транспорту та зв’язку; науково-дослідних установах [4].

Фахівець з комп’ютерної інженерії повинен уміти створювати та здійснювати монтаж та експлуатацію розподілених комп’ютерних систем, адмініструвати мережі та системи, створювати та здійснювати експлуатацію комп’ютерних пристроїв і комплексів, створювати прикладне та системне програмне забезпечення, інсталювати програми, створювати бази даних, отримувати доступ до інформаційних ресурсів Internet [4].

Після закінчення ВН3 за напрямом підготовки 6.050102 «Комп’ютерна інженерія» бакалавр $з$ комп’ютерної інженерії може обіймати посади, передбачені для заміщення фахівцями з базовою вищою освітою в галузі інформатики та обчислювальної техніки номенклатурами посад промислових підприємств, проектно-конструкторських та наукових організацій, підприємств, організацій житлово-комунального та сільського господарств; об’єктів автомобільного, комунального та внутрішньозаводського транспорту; різного роду структур, профіль яких або окремі напрями діяльності відповідають отриманій спеціалізації [2]:

- технік із системного адміністрування;

- технік-програміст;

- фахівець з інформаційних технологій;

- фахівець з комп’ютерної графіки (дизайну);

- фахівець з розроблення та тестування програмного забезпечення;

- фахівець з розроблення комп'ютерних програм;

- диспетчер електрозв'язку;

- диспетчер поштового зв'язку;

- технік електрозв'язку;

- технік з радіолокації;

- технік з сигналізації;

- технік із конфігурованої комп'ютерної системи;

- технік із структурованої кабельної системи;

- технік обчислювального (інформаційно-обчислювального) центру;

- технік поштового зв’язку; 
- технік-конструктор (електроніка);

- технік-технолог (електроніка).

Професійна діяльність фахівця з комп’ютерної інженерії полягає у виконанні таких видів робіт [5]:

- виробництво електричного, електронного й оптичного устаткування, виробництво електронно-обчислювальних машин та іншого устаткування для оброблення інформації, монтаж і встановлення електронно-обчислювальних машин та іншого устаткування для оброблення інформації, виробництво електро- та радіокомпонентів;

- консультування з питань інформатизації, розроблення стандартного програмного забезпечення, інші види діяльності у сфері розроблення програмного забезпечення, оброблення даних, діяльність, пов’язана з банками даних, ремонт і технічне обслуговування електронно-обчислювальної техніки, інша діяльність у сфері інформатизації.

Основні напрями професійної діяльності- організаційна, проектувальна, технологічна, дослідницька. Фахівець 3 інформаційних технологій за умов набуття відповідного досвіду може адаптуватися до таких напрямів суміжної професійної діяльності: адміністративно-господарська, обліково-контрольна, освітня, науково-дослідницька.

У 2011-2012 н. р. підготовка бакалаврів комп’ютерної інженерії здійснювалась у 60 ВНЗ України; у 2012-2013 н. р. - у 64 ВН3, у 2013-2014 н. p. - у 67 ВН3, у 2014-2015 н. р. - у 63 ВНЗ України [1]. Ліцензований обсяг прийому на підготовку бакалаврів комп’ютерної інженерії (близько 8 тис. студентів щорічно) є непрямим свідченням суспільного замовлення на підготовку бакалаврів з комп’ютерної інженерії. Тому одначена проблема $є$ актуальною.

Перехід до нового покоління стандартів підготовки фахівців на основі компетентнісного підходу вимагає розвитку сформованих зв'язків - від міжпредметних до міжкомпетентнісних, від загальнонаукових та інструментальних до загальнопрофесійних та спеціальнопрофесійних.

Галузевий стандарт вищої освіти України (ГСВОУ) за напрямом підготовки 6.050102 «Комп’ютерна інженерія» визначає перелік компетентностей щодо розв’язання певних проблем і задач соціальної діяльності, інструментальних, загальнонаукових і професійних компетентностей. До основних компетентностей, що визначаються освітньо-кваліфікаційною характеристикою (OKX) бакалаврів 3 комп’ютерної інженерії, належать: соціальноособистісні, загальнонаукові, інструментальні, загальнопрофесійні, спеціалізованопрофесійні [5].

Виробничі функції, якими повинні володіти бакалаври 3 комп’ютерної інженерії: дослідницька (математичні перетворення та розрахунки, розрахунки фізичних параметрів ТО, розрахунки електричних кіл, розрахунки імовірнісних та статистичних характеристик ТО, чисельні розрахунки, аналіз та синтез дискретних об’єктів, розроблення електронних схем); організаційна (охорона навколишнього середовища, організація обчислювальних процесів, захист інформації, забезпечення охорони праці та безпеки життєдіяльності); проектувальна (розроблення програм, синтез комбінаційних схем, розроблення архітектури комп’ютера, розроблення типового вузла і пристрою ТО, розроблення системних програм, розроблення паралельних і розподілених комп’ютерних систем, розроблення комп'ютерних мереж, програмування для паралельних та розподілених комп’ютерних систем, робота 3 базами даних, розроблення великих програмних систем), технологічна (автоматизація проектування ТО).

Для підготовки висококваліфікованого сучасного інженера необхідна якісна фундаментальна підготовка, що є основою фахової підготовки інженера. 
Згідно з освітньо-професійною програмою (ОПП) підготовки бакалавра за напрямом 6.050102 «Комп’ютерна інженерія» навчальний час теоретичної і практичної підготовки, відведений на засвоєння освітньо-професійної програми бакалавра, становить 8640 годин, або 240 кредитів ECTS, i передбачає нормативну і варіативну частини [5]. Розподіл загального навчального часу відповідно до навчального плану підготовки бакалавра за напрямом 6.050102 «Комп’ютерна інженерія» подано у таблиці 1.

Таблиця 1

Розподіл загального навчального часу за циклами підготовки

\begin{tabular}{|c|c|c|}
\hline \multirow[b]{2}{*}{$\begin{array}{c}\text { Цикл підготовки } \\
\text { (термін навчання - } 4 \text { роки) }\end{array}$} & \multicolumn{2}{|c|}{ Загальний навчальний час } \\
\hline & Кредитів ECTS & $\begin{array}{l}\text { Співвідношення } \\
\text { аудиторні години / } \\
\text { самостійна робота }\end{array}$ \\
\hline \multicolumn{3}{|c|}{ Нормативна частина } \\
\hline $\begin{array}{l}1.1 \text { Цикл гуманітарної та соціально- } \\
\text { економічної підготовки }\end{array}$ & 24 & 306 / 342 (864) \\
\hline $\begin{array}{l}1.2 \text { Цикл математичної, природничо- } \\
\text { наукової підготовки }\end{array}$ & 41 & 936 / 1026 (1476) \\
\hline $\begin{array}{l}1.3 \text { Цикл професійної та практичної } \\
\text { підготовки }\end{array}$ & 100 & 990 / 2034 (3600) \\
\hline Всього за нормативною частиною & 165 & $2232 / 3402(5940)$ \\
\hline \multicolumn{3}{|c|}{ Варіативна частина } \\
\hline $\begin{array}{l}2.1 \text { Цикл дисциплін самостійного вибору } \\
\text { навчального закладу }\end{array}$ & 55 & 1197 / $1269(1980)$ \\
\hline $\begin{array}{l}2.2 \text { Цикл дисциплін вільного вибору } \\
\text { студентів }\end{array}$ & 20 & 270 / $270(720)$ \\
\hline Всього за варіативною частиною & 75 & $1467 / 1539(2700)$ \\
\hline Всього за 4 роки & 240 & 3699 / 4941 (8640) \\
\hline
\end{tabular}

Частка дисциплін циклу математичної, природничо-наукової підготовки досить велика - 17 \% (рис. 1), зокрема на дисципліну «Фізика» передбачено 270 годин (5 кредитів ECTS), що складає 18 \% від загальної кількості дисциплін цього циклу (рис. 2). Отже, фізика є фундаментальною дисципліною у підготовці бакалавра з комп’ютерної інженерії.

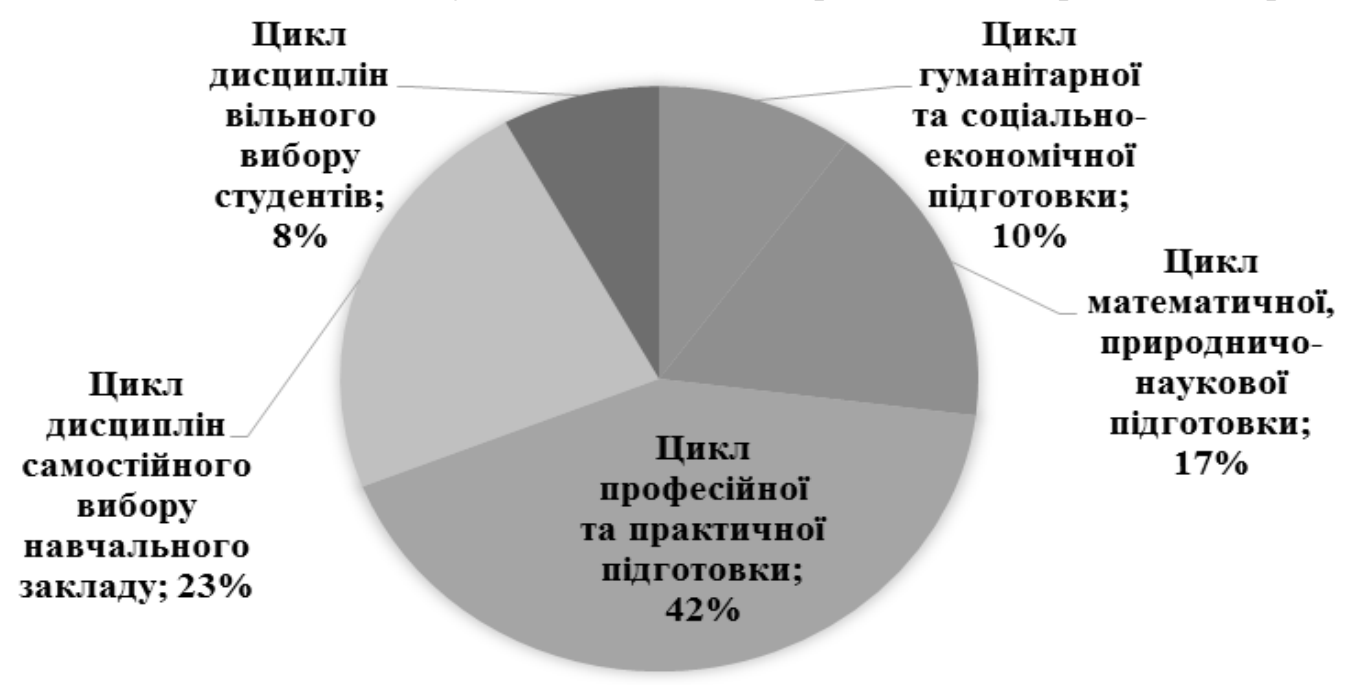

Рис. 1. Розподіл навчального часу за циклами підготовки бакалаврів за напрямом 6.050102 «Комп’ютерна інженерія» 


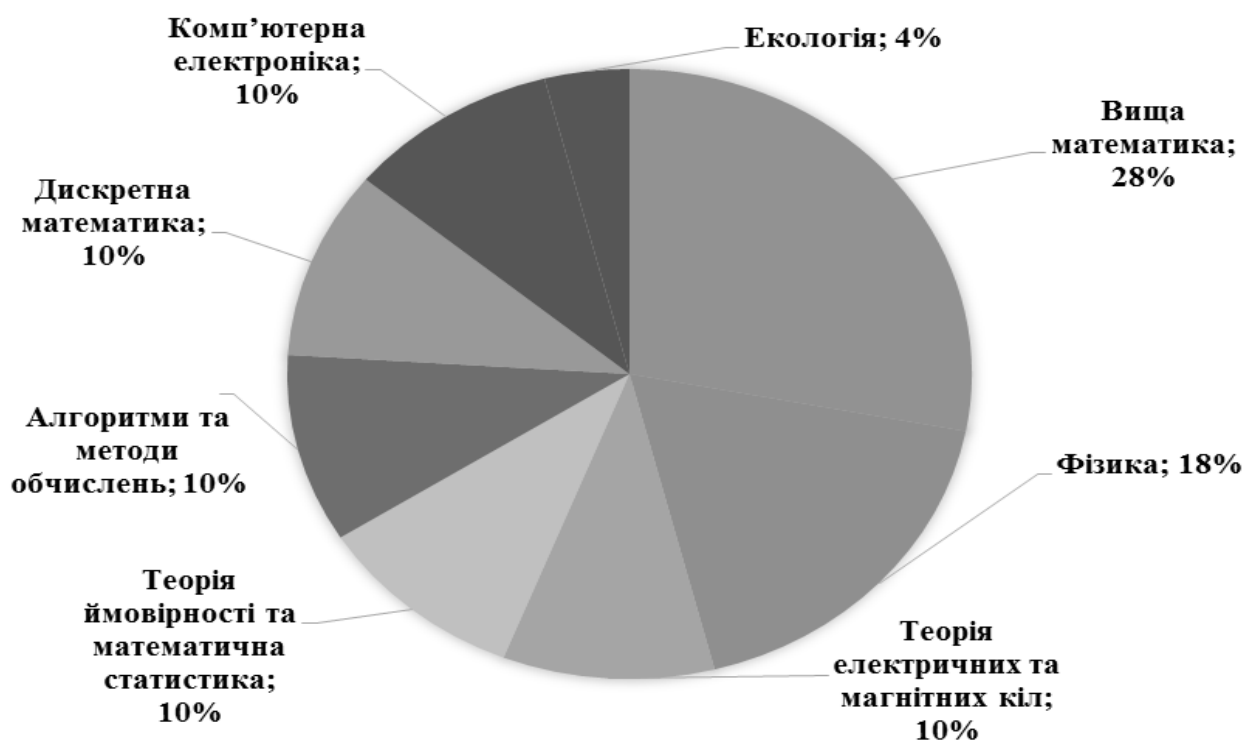

Рис. 2. Розподіл годин за дисциплінами циклу математичної та природничо-наукової підготовки

Відповідно до ОПП бакалаврів комп’ютерної інженерії, навчальна дисципліна «Фізика» складається зі змістових модулів «Механіка», «Електрика і магнетизм», «Оптика», «Квантова фізика» та розкривається в таких темах: «Кінематика і динаміка», «Моделі класичної механіки», «Робота та енергія», «Основи теорії відносності», «Електричне поле», «Постійний електричний струм», «Змінний електричний струм», «Магнітне поле», «Електромагнітна індукція. Рівняння Максвела», «Хвильова оптика», «Інтерференція. Дифракція. Поляризація. Дисперсія», «Теплове випромінювання. Фотони», «Модель атома. Рівняння Шредінгера», «Елементи фізики твердого тіла».

Вивчення програм з дисциплін циклу професійної та практичної підготовки дає підстави стверджувати, що поняття та методи фізики систематично використовуються під час вивчення багатьох спеціальних технічних дисциплін (таблиця 2).

Таблиця 2

Розділи фізики, що використовуються при вивченні дисциплін циклу професійної та практичної підготовки напряму

6.050102 «Комп'ютерна інженерія»

\begin{tabular}{|l|l|}
\hline \multicolumn{1}{|c|}{ Навчальна дисципліна } & \multicolumn{1}{|c|}{ Розділи навчальної дисципліни «Фізика» } \\
\hline Архітектура комп’ютерів & «Електрика і магнетизм» \\
\hline Програмування & «Механіка», «Електрика і магнетизм» \\
\hline Системне програмування & «Механіка», «Електрика і магнетизм» \\
\hline Комп’ютерна схемотехніка & «Електрика і магнетизм» \\
\hline $\begin{array}{l}\text { Безпека життєдіяльності } \\
\text { основи охорони праці }\end{array}$ & «Механіка», «Електрика і магнетизм», «Оптика» \\
\hline
\end{tabular}

Аналіз структури та змісту навчальних дисциплін циклів природничо-наукової, математичної й професійної та практичної підготовки майбутніх фахівців 3 комп’ютерної інженерії показав, що фізика є основою їх професійної підготовки. Відповідно до освітньокваліфікаційної характеристики, грунтовна підготовка 3 фізики включена до групи професійних компетенцій бакалаврів 3 комп’ютерної інженерії, а не до групи 
загальнонаукових компетенцій, як за спорідненими напрямами підготовки. У зв’язку з цим навчання фізики бакалаврів 3 комп'ютерної інженерії повинно бути спрямованим на формування професійних виробничих функцій майбутнього фахівця, провідними 3 яких $є$ проектувальна (насамперед із розроблення програмних та комп'ютерних компонентів) та дослідницька (насамперед з комп’ютерного моделювання). Це створює умови для залучення до процесу навчання фізики засобів IKT, що надають можливість створення й дослідження комп’ютерних моделей фізичних процесів.

\section{Література}

1. Інформаційна система «Конкурс» [Електронний ресурс]/ Міністерство освіти і науки України, ГО «Центр освітньої політики». - 2008-2015. - Режим доступу : http://vstup.info. 2. Національний класифікатор України «Класифікація видів економічної діяльності» (КВЕД). ДК 009 : 2005 [Текст] : станом на 10 груд. 2010 р. - Київ : Центр учбової л-ри : ВМГО «Укр. молодіж. правничий союз», 2011. - 223, [1] с. 3. Національний класифікатор України «Класифікатор професій» ДК 003 : 2010. Станом на 11.04.2011 р.Київ : Центр учбової літератури, 2011. - 360 с. 4. Освітньо-кваліфікаційна характеристика бакалавра. Галузь знань 0501 «Інформатика та обчислювальна техніка». Напрям підготовки 6.050102 «Комп’ютерна інженерія». - Офіц. вид. - Київ : Міністерство освіти і науки, молоді та спорту України, 2011.- (Галузевий стандарт вищої освіти України). 5. Освітньопрофесійна програма бакалавра. Галузь знань 0501 «Інформатика та обчислювальна техніка». Напрям підготовки 6.050102 «Комп’ютерна інженерія». - Офіц. вид. - Київ : Міністерство освіти і науки, молоді та спорту України, 2011. - (Галузевий стандарт вищої освіти України).

Микола Стрюк

\section{ТЕНДЕНЦІЇ РОЗВИТКУ МОБІЛЬНОСТІ СТУДЕНТІВ ТА МОЛОДИХ НАУКОВЦІВ У ЄВРОПЕЙСЬКОМУ ОСВІТНЬО-НАУКОВОМУ ПРОСТОРІ}

Стрюк М. І. Тенденції розвитку мобільності студентів та молодих науковців у європейському освітньо-науковому просторі.

У статті виокремлено нові напрями реалізації мобільності студентів, аспірантів та викладачів у Європейському освітньо-науковому просторі, застосування яких в Україні сприятиме підвищенню конкурентоздатності вітчизняної системи освіти. Особливу увагу приділено шляхам розв’язання проблеми «витоку мізків».

Ключові слова: академічна мобільність, мобільність студентів та аспірантів, програми мобільності, постачальники мобільності, віртуальна мобільність, «витік мізків».

Стрюк Н. И. Тенденции развития мобильности студентов и молодых ученых в европейском образовательно-научном пространстве.

В статье выделены новые направления реализации мобильности студентов, аспирантов и преподавателей в Европейском образовательно-научном пространстве, применение которых в Украине будет способствовать повышению конкурентоспособности отечественной системы образования. Особое внимание уделено путям решения проблемы «утечки мозгов».

Ключевые слова: академическая мобильность, мобильность студентов и аспирантов, программы мобильности, поставщики мобильности, виртуальная мобильность, «утечка мозгов». 